\title{
Awareness of the Antibiotics Growth Promotors (AGP) and Its Application in Chicken Feed
}

\author{
Sumanto \\ Indonesian Research Institute for Animal Production \\ PO Box 221, Bogor 16002, West Java, Indonesia \\ sumanto_d@ymail.com
}

\begin{abstract}
A study was carried on the public opinion against the banning of the use of AGP farms (antibiotics growth promotor) in feed, indicated in the Directorate General of Livestock Act of Animal Husbandry No $18-2009$ Article 22 verse 4C. Surveys with "purposive sampling" to the farming communities was implemented in June to November 2015. The results showed that the use of feed additive AGP in the feed industry is still not much known by respondents that were supposed to be harmful to human health. So, we need to do a socialization about the danger of AGP to all community. Most opinion of the Government and stakeholder agreed to prohibit the use of AGP in feed. It is recommended that the implementation of AGP banning is not done all in a sudden. Replacement materials of AGP in the form of herbal, probiotics and enzymes have been used by farmers, but it is still limited however they realized it is useful to increase health and the productivity of the animal.
\end{abstract}

Key Words: Antibiotics Growth Promotor, Opinions, Antibiotics, Feed Additives, Livestock

\section{INTRODUCTION}

Demand for meat as source of animal proteins in Indonesia, mostly contributed by poultry, i.e. chicken broiler and its impact need to be provided sufficient fodder. The manufacture of animal feed broilers or layers based on the energy and protein needs. Addition of antibiotics growth promoters (AGP) has developed useful to enhance the durability and productivity of livestock, but if livestock products (such as meat) are consumed by humans too much will cause the human body to be immune to antibiotics.

Antibiotics are developing and are already used in animal feed, such as tylosin and penicillin (Samadi 2015). Antibiotic manufacture of chemicals in developed countries must already meet economically scale. The use of antibiotics in cattle are supposed to improve production efficiency significantly. Tangenjaya (2015) reported that drugs and AGP koksi helpful to fix feed conversion ratio (FCR), between 2 to $20 \%$. Food that is required for the production of broiler weighs $1.7 \mathrm{~kg}$ plus $2.8 \mathrm{~kg}$ of feed needed for the cost of adding the drug and AGP koksi IDR 200/head. Further he said that the production of chickens in Indonesia about 2.5 billion heads/year, thus the cost of anti-koksi and AGP IDR 500 billion/year, but the potential profits reached IDR 2.7 trillion/year.

The use of AGP antibiotics will produced animal food such as meat, eggs and milk are free from pollution. The animal feed used can increase the life expectancy of people, but on the other hand can cause resistant and still contained harmful chemical residues (antibiotics, dioxin) and microbiology dangerous (Salmonella). To overcome this problem, some developed countries Sweden (1986), Denmark (1995), Germany (1996) and Switzerland (1999) have restricted the use of antibiotics in livestock feed (Samadi 2015). In Indonesia, whether the use of antibiotics in animal feed still allowed is still question mark.

According Tangenjaya (2015) that the use of anti-koksi and AGP can ward off harmful bacteria in the growth and production of laying hens and broilers. All these 
materials follow the rules in terms of both the type and amount of usage including stoppage time. The results of the study reported that the drug toxic and AGP does not lead to residues when used according the instructions. Even in Indonesia found residues in meat and eggs in groups teracycline are not mixed in the feed. The results of the study on probiotics "Petro Chick" testified that can improve the performance of broilers in small and large-scale enterprises (Rendy 2014).

Anticipating the impact of AGP in animal feed in Indonesia, Directorate General of Livestock has issued Law No. 18 of 2009 Article 22, paragraph 4c prohibiting uses of feed mixed with certain hormones and/or antibiotic feed additives. But the law could be enforced through the government regulation (GR), which regulates more about these rules, which now they are still missing yet. It required an initial review of the ban on public opinion of users or government and the use substitute materials such as herbs antibiotics as feed additive that can increase the productivity of poultry. The aim of this activity is to inform the development of the use of AGP and information about the opinions or views when the AGP in animal feed banned and anticipate any successor or alternative material (herbs) that will be or has been used.

\section{MATERIAL AND METHODS}

\section{Material}

Basic discussion is to obtain information and public opinions about the development of Law No. 18 of 2009, article 22, paragraph 4c which states that anyone banned of using feed mixed with certain hormones and/or antibiotic feed additives. It has carried out a study for the public opinion about the ban farms addressed to government (animal husbandry), researchers, farmers, groups of farmers (cooperatives), feed mills and livestock medicine company. The information captured includes resources, in response to the ban on the use of prefixes antibiotics, and the use of alternative herbal ingredients in breeding poultry and beef cattle.

\section{Methods}

Information opinion on the act banning the use of antibiotics in feed additive obtained from 61 respondents who were selected and interviewed in "purposive sampling", which were divided into two groups: (A) Representation of government; and (B) Users are represented from small farmers, cooperatives, large farmers, feed mills and livestock medicine company. This survey activities conducted at June to November 2015 in Serang, Sukoharjo, Semarang and Surabaya. Selection of the cities was based on the survey that the location is an area of poultry and beef and there is also a medicinal plant farm (Semarang, Sukoharjo). Information collected is tabulated and described descriptively.

\section{RESULTS AND DISCUSSION}

\section{Resources information}

In order to get public opinion on the farm about banning the use of antibiotics which stated in Law No. 18 of 2009, section 22. Section 4c, it has done a number of interviews to 61 respondents with backgrounds different jobs are categorized two groups, namely: government and users, with details of the number of respondents each group as listed in Figure 1. 


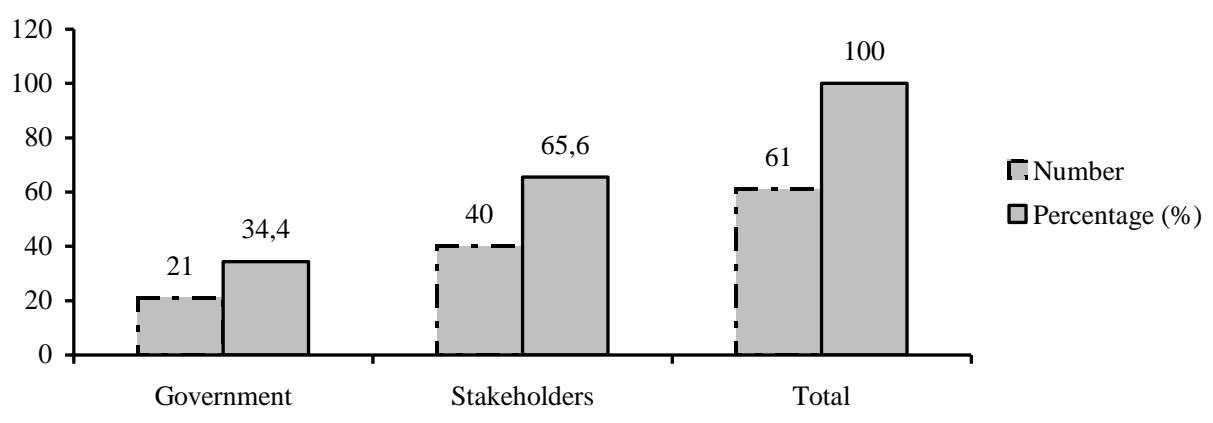

Figure 1. Sources of information respondent

It appears that the information from the government are as many as 21 people (34.4\%), which is a combination between researchers and livestock government officials. The government is represented by the local animal husbandry department officials and Drug Center in Tawangmangu. While the number of respondents from the user as much as 40 people $(65.6 \%)$, which is a combination of small farmers, cooperatives, large farmers, feed mills and livestock medicine company (private). Cooperatives are generally sought in poultry and the private company on the activities of veterinary medicines, animal feed and herbs.

\section{Opinion prohibition plan antibiotics in feed}

Opinion of respondents to the Law No. 8 of 2009, concerning the use of AGP in the feed will be prohibited can be seen in Figure 2. The two groups of respondent opinion expressed in answers to agree, disagree and abstain, as shown in Figures 2 and 3. In the group of government (Figure 2) states that the number respondents who agree the ban on the use of AGP in feed as much as $81.0 \%$ of respondents who abstained as much as $9.5 \%$ and disagree only $9.5 \%$.

Opinion on law No. 18-2009, the ban on the use AGP-goverment

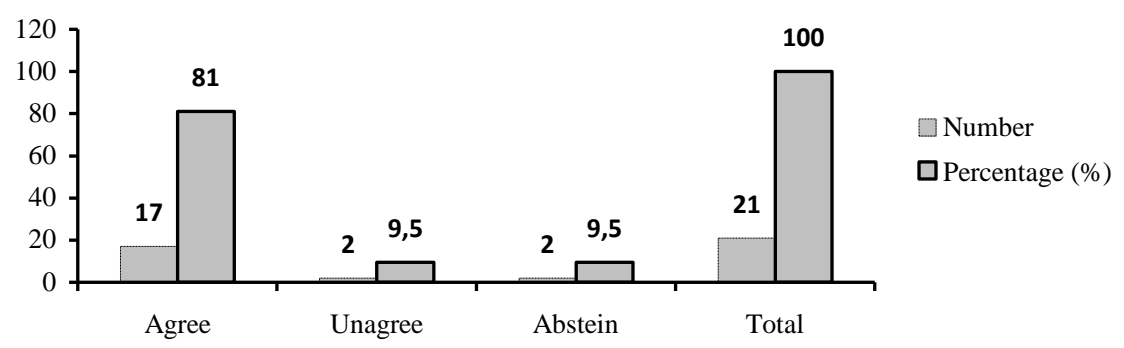

Figure 2. Government's responses on prohibition of using AGP in feed

While user groups (Figure 3) states that the number respondents who agree the ban on the use of AGP in feed as much as $72.5 \%$ of respondents who abstained as much as $25.0 \%$ and disagree only $2.5 \%$. 
Opinion on law No. 18-2009, the ban on the use AGP-stakeholder

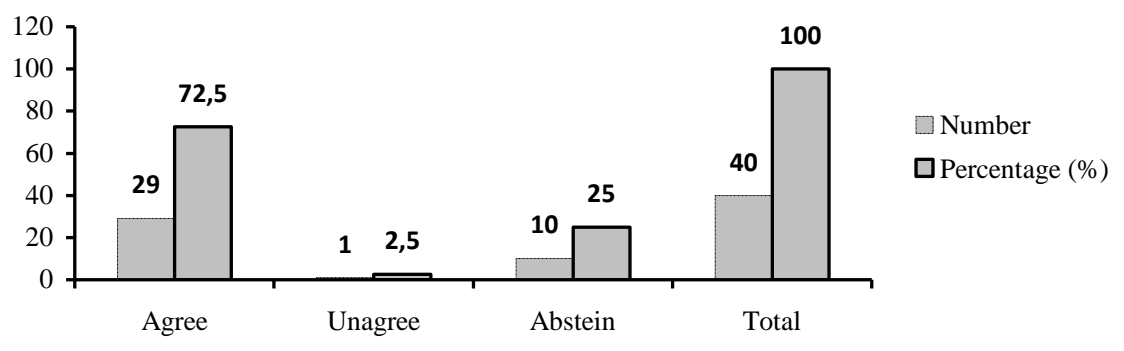

Figure 3. User's responses on prohibition of using AGP in feed

Time banning the use of AGP in the feed was said by respondent should be given time and unhurried (1-2 years), so that farmers and feed makers have enough time to make preparations well. Hopefully, by delaying the ban, farmers can make preparations to produce the replacement of feed ingredients in herbal, the medicinal makers or animal feed can prepare herbal or medicine as an additive feed in poultry. It is also in line what is suggested by Tangenjaya (2015).

\section{Opinion the use of AGP in animal feed}

AGP is generally believed to be added in animal feed, particularly for commercial feed broiler chickens. Respondent had been interviewed to assess the extent to which respondents are already understood that commercial feed has been added AGP. The answer is stated in the statement yes, no and did not know to use AGP. In the group of government, as much as $52.4 \%$ of respondents claimed to have learned that the feed does not contain AGP, $19.0 \%$ do not use AGP and rest as much as $28.6 \%$ of respondents answered do not know (Figure 4).

Opinion of AGP used in feed-goverment

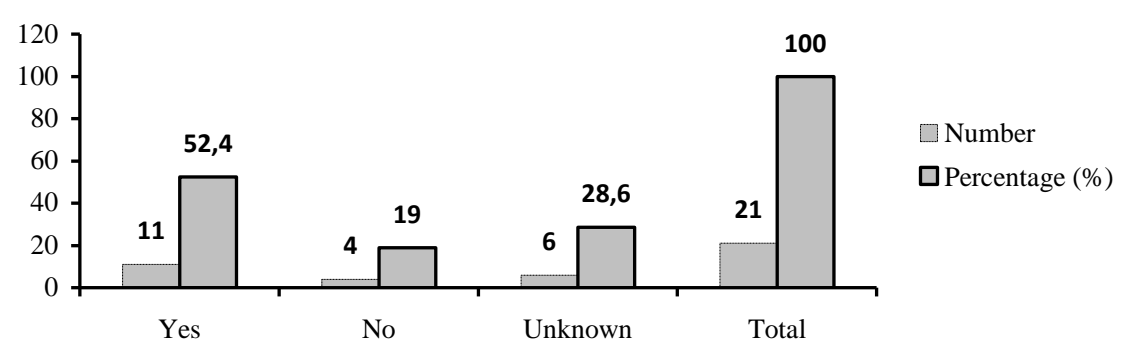

Figure 4. Gorvernment's responses of using AGP in animal feed

Then the user groups, as many as $52.5 \%$ of respondents claimed to have learned that the feed does not contain AGP, 42.5\% do not use AGP and rest as much as $5.0 \%$ of respondents answered do not know (Figure 5). 
Opinion of AGP used in feed-stakeholders

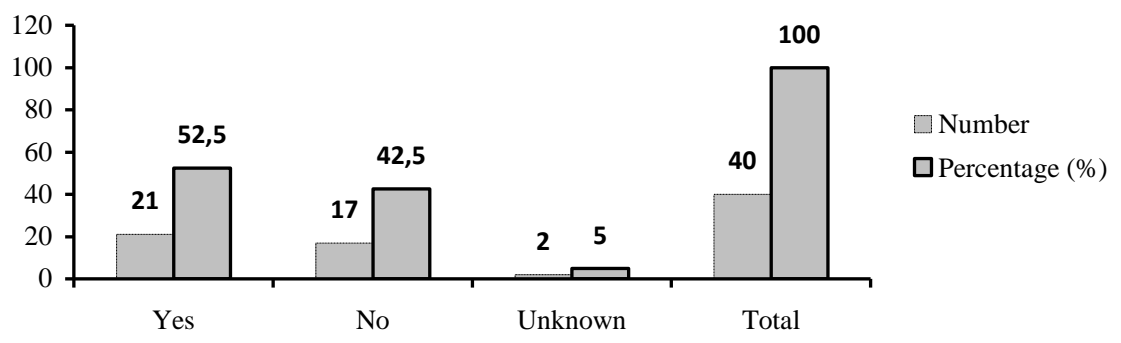

Figure 5. User's responses of use AGP ini animal feed

Not many respondents know about AGP in animal feed, it is necessary to disseminate the activities of the dangers of the use of AGP in animal feed. In addition, respondents who stated fodder there AGP expect increased productivity and healthier livestock. The addition of AGP in animal feed make livestock be healthy and grow faster (Sumpana \& Deasy 2010). But using the AGP in animal feed was allegedly getting higher and if livestock products are consumed by humans, it will be damaged immune (Gayoeon 2015; Heriana 2015).

\section{Material feed additives replacement AGP}

Respondents who already know and have experience on using substitute materials as feed additives AGP answer more than one answer provided. In the group of government, they said that the names of the substitutes AGP ever known or used in feed mixtures are materials affixes organic acid (42.86\%), enzyme (47.62\%), probiotics (47.62\%), prebiotics (28.57\%), synbiotic (33.33\%), and herbal (57.14\%) shown in Figure 6.

Opinion substitute AGP-goverment

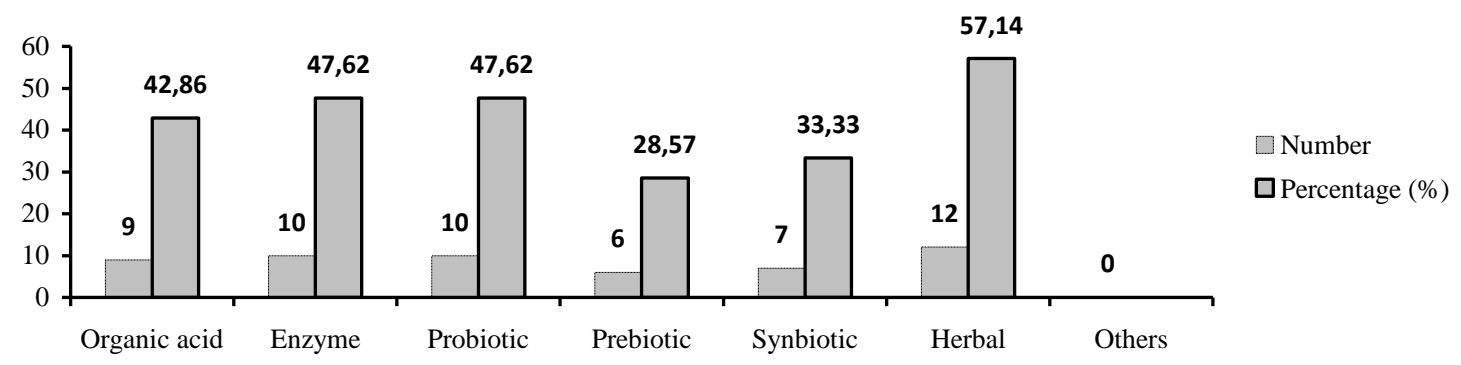

Figure 6. Feed additive name instead of AGP, stated by government's respondent

While in the group user, they said that the names of the substitutes AGP which have been used in feed mixtures are materials affixes organic acids (32.5\%), enzymes (42.5\%), probiotics $(40.0 \%)$, prebiotics $(15.0 \%)$, synbiotic $(22.5 \%)$, herbal $(37.5 \%)$ and others (brotoxin, forage) $(10.0 \%)$ are shown in Figure 7. 
Opinion substitute AGP-stakeholders

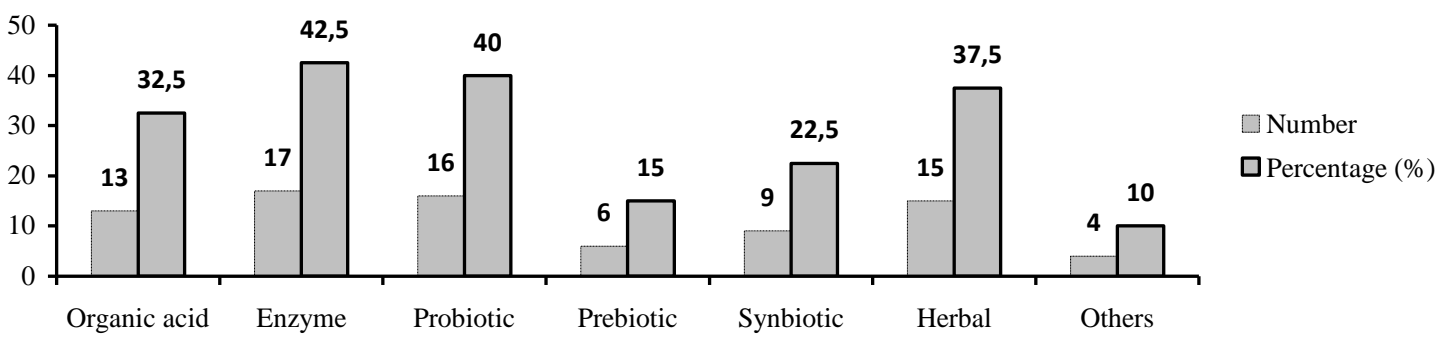

Figure 7. Feed Additive Name Istead of AGP- User's Responses

Probiotic microbes such as Bacillus amyloliquefaciens can replace antibiotics in broiler chickens and have a positive impact in terms of health and economic (Budiansyah 2004). Additional use of probiotics (Lactobacillus and Bacillus) in chicken feed could replace antibiotic (Adnan 2011). Herbal ingredients, such as turmeric, kencur, noni leaf, ginger has been used by farmers for buffalo, sheep, ducks and chickens locally in Banten, but does not used continuously with the aim of improving the health of cattle that are sick and also as a veterinary drug after childbirth. Ognik et al. (2016) states that the use of garlic, aloe vera, and oregano can stimulate antioxidant mechanisms to improve the health and productivity of chickens. The same was done breeder laying hens in the CV. Berkah Gemilang in Desa Plesan, Nguter, Sukoharjo. Packaging Herbal medicine has been widely used in ruminant livestock, particularly for fattening purposes, such as that experienced breeders of beef cattle in the group "Andini Lestari", Lalung village, Karanganyar.

\section{CONCLUSION}

AGP Feed Additives in animal feed is still not known by many respondents were suspected to harm human health. It is necessary to socialize the danger of using AGP. The Government and other stakeholders largely agreed to ban the use of AGP in animal feed, as stated in the Law on Livestock No. 18 Year 2009 Article 22, Paragraph 4c. But the timing of the ban on animal feed AGP is not suddenly done. AGP substitute materials in the form of herbs, probiotics and enzymes have been used in animal feed, but is still limited. However they have realized the benefit on increased productivity and animal health.

\section{ACKNOWLEDGEMENT}

The author would like to thank colleagues research team: Prof. Arnold Sinurat, E. Juarini, Susan IWR, Dr. Elizabeth Wina, and Tuti Hariati who have helped in gathering the necessary information

\section{REFERENCES}

Adnan K. 2011. Efek penggunaan probiotik sebagai pengganti antibiotik pada pakan. [Internet]. [cited 7 Mei 2016]. Available from: http://dokterternak.com/2011/04/26/probiotik-penggantiantibiotik-pada-pakan-ternak-broiler-layer-sapi-kambing/.

Budiansyah A. (2004). Pemanfaatan probiotika dalam meningkatkan penampilan produksi ternak unggas. Bogor (Indonesia): Institut Pertanian Bogor. 
Gayoeon E. 2015. Waspadalah terhadap penggunaan antibiotik terhadap hewan ternak. [Internet]. [cited 7 May 2016]. Available from: http//www.hariandepok.com/31287/waspadalahterhadap-penggunaan-antibiotik-terhadap-hewan-ternak.

Heriana LC 2015. Pemakaian antibiotik pada ternak makin mengancam kesehatan manusia. [Internet]. [cited 7 May 2016]. Available from: http://food.detik.com/read/2015/12/23/110431/ 3103030/900/pemakaian-antibiotik-pada-ternak-makin-mengancam-kesehatan-manusia.

Ognik K, Cholewinska E, Sembratowicz I, Grela E, Czech A. 2016. The potential of using plant antioxidants to stimulate antioxidant mechanisms in poultry. World's Poult Sci J. 72:291-298.

Rendy A. 2014. Tingkatkan produktivitas ayam. [Internet]. [cited 30 Desember 2015]. Available from: http://sahabat petani.com/tingkatkan-produktivitas-ayam/.

Samadi. 2015. Antibiotik dalam pakan. Majalah Infovet [Internet]. [cited 26 Desember 2015)]. Available from: http://www.majalahinfovet.com/ 2008/07/antibiotik-dalam-pakan-ternak.html

Sumpana AF, Deasy C. 2010. Probiotik sebagai pengganti antibiotik pada pakan ternak. Malang (Indonesia): Universitas Ma Chung.

Tangenjaya B. 2015. Implikasi kebijakan penghentian antibiotic growth pomotor (AGP) dan antikoksi. Poultry Indonesia. [Internet]. [cited 26 Desember 2015)]. Available from: http://www.poultryindonesia.com/news/opini/implikasi. 